\title{
Applying Reciprocal Teaching Method in Teaching Reading
}

\author{
Moh. Rodli ${ }^{1 *} \&$ Hari Prastyo ${ }^{2}$ \\ ${ }^{1}$ Madrasah Aliyah Negeri (State Islamic High School), Mojokerto, Indonesia \\ ${ }^{2}$ Islamic Institute of Uluwiyah, Mojokerto, Indonesia \\ * Moh. Rodli, E-mail: rodli2002@gmail.com
}

Received: May 27, 2017

doi:10.22158/sll.v1n2p112
Accepted: June 20, 2017

Online Published: July 11, 2017

URL: http://dx.doi.org/10.22158/sll.v1n2p112

\begin{abstract}
Reading is one of English language skills considered more important in this modern world, so reading gets more emphasize than other skills. Although receiving more attention than other language skills in English classroom, the result of students' reading comprehension achievement is still far from expectation. To help students comprehend English reading texts and have better achievement in reading skill, Reciprocal Teaching method can be an alternative to offer. The Reciprocal Teaching method as an instructional activity that takes place in the form of dialogue, which is structured by the use of four steps: predicting, clarifying, question generating, and summarizing. Students learn to use four strategies to increase their understanding of the text being read. This method is useful for improving students' reading effectiveness, in addition to help students better remember what they read. This paper highlights the Reciprocal Teaching method and its use as an alternative to improve students' reading comprehension achievement.
\end{abstract}

\section{Keywords}

reading, Reciprocal Teaching

\section{Introduction}

Reading is one of English language skills considered important for students' growth as an individual in many aspects of life. Every day we cannot escape from reading activity. We read newspaper, report, messages, books, notes, and many other writings. So reading has been considered as one of the major sources of providing students with great amount of information about various subjects (Salehi \& Vafakhah, 2013, p. 148). That is why students are taught reading skill at school. By reading, the students will know how English is actually used in printed and written forms.

According to Rivers (1981, p. 259) the most important activity in any language class is reading. Reading is not only a source of information and a pleasurable activity, but also a means of consolidating one's knowledge of a language. In other words, reading activities can bring many benefits for students such as to get information, pleasure and knowledge. Furthermore, Nunan (1991, p. 259) states that reading is the most important activity in any class not only as a source of information, a 
pleasurable activity, but also a means of consolidating and extending one's knowledge, literature, and culture. So the knowledge or information which students get from the reading activity in the classroom hopefully can give meaningful contribution in every aspect of life (Gillet \& Temple, 1994, p. 3).

According to Burns et al. (1996, p. 5) the ability to read is vital to functioning effectively in a literate society. However, students who do not understand the importance of learning to read will not be motivated to read. Justify Burns' opinion, Bruder and Henderson (1988) state that the ability to read can be affected by some factors, such as linguistic aspects, prior knowledge, and reading strategy. Dealing with the linguistic aspects, mastering relevant vocabulary items and structures become a basis for which a student decodes meaning from the text. Another factor is prior knowledge that students bring into reading. When students are reading a text, they are not passive; instead, they bring their prior knowledge to incorporate with new information within a text. Meanwhile, the use of strategy in reading brings about some benefits for which the students might adjust their purpose for reading and become aware of what they were reading.

Referring to the importance of reading, the students should be well prepared with the skill as early as possible so they are accustomed to comprehending what they read in their daily life. Leipzig (2001, p. 1) states that in reading activity we are not only reading the text, but also trying to understand what we are reading. It is based on the fact that reading requires words recognition, comprehension, and fluency.

Djiwandono (1996, p. 63) also states that to understand all types of information in an array of the text requires not only the reading activity but also ability to understand the content. In addition, he asserts that without the ability to understand the content, one cannot absorb or comprehend a lot of information quickly, accurately, and easily. Accordingly, reading should become the main emphasis in English teaching program in Indonesia, particularly for the senior high school students. Yet it does not mean that the other skills of English like listening, speaking, and writing are not important.

Unfortunately, reading at the secondary and higher school still becomes problem for students. Alderson (1984) states that when the students are confronted with a reading text, they seem to read with limited understanding. Furthermore, Students mostly are still experiencing reading difficulties in reading learning process. Most problems are lack of vocabularies, lack knowledge of sentence structures, difficulties in discovering the meaning of words in context and also improper classroom activities. Inadequate vocabulary makes them stumble at each sentence, and soon they begin to lose their patience with and interest in reading (Rahman, 2007, pp. 32-33). This is because if the students faced a difficult text with many unknown words, the students of course will look for it in a dictionary in many times. This will make the students become boring and lose their interest in reading.

So, Limited knowledge of vocabulary and lack of sentence structure is regarded as the main problem (Gunning, 2002 in Chawwang, 2008, p. 2). Lacking of sentence structures knowledge also lead the students to become frustrated in reading activity. As we know, sentence structures will makes the readers know about what the function of the words are, when the sentence expected by the author to be happened, and many others. The complex sentences that contain complex sentence structures will break 
the students' mental down because they cannot gain the real meaning of a sentence and this will intrude the students' success in reading. Some students also cannot discover the meaning of words in context. Actually students need to imply meaning by guessing from sentences or context (Aebersold \& Field, 1997 in Chawwang, 2008, p. 2). But the students sometimes only know one meaning of a word. This will lead a misunderstanding in interpreting the meaning of a sentence. It also causes confusion for students in understanding a text.

Improper classroom activities are also responsible for students' poor reading (Rahman, 2007, p. 34). A proper classroom learning activities should be applied in reading learning process. A proper instruction in reading learning process will help the students read in a right way.

According to Yaseen (2013, pp. 2-3) in reading class in some schools, teachers ask the whole class to repeat after them, then one by one to sound out words. Sometimes they read for the class and then ask the students one by one to read loudly. Sometimes they focus on every single word, how it is pronounced and what it means. Those explanations by Yaseen are often happened in the reading class. Those will create an inappropriate interaction between teacher and the students. The students will have misunderstanding of what reading is and they will think that "just read fast with correct pronunciation, and you are a good reader". Those improper reading instructions sometimes will make the students consider that reading is an unimportant and passive activity than ignore it. Reading is such a passive activity but actually it is not. Reading is an active activity because it involved our brain to work consciously or unconsciously to gain information if the right strategy is applied.

Considering the above causes, it is necessary to implement a strategy that can help solve the students' problems in reading. One of the strategies that helps students understand reading materials is Reciprocal Teaching (RT) method. RT method is originally developed by Palincsar and Brown (1984) and they describe it is as problem solving activities that aim to promote thinking while reading, resulting in better comprehension of the reading passage (Salehi \& Vafakhah, 2013). It is a step by step procedure and emphasize in four reading strategies that a teacher or tutor and a group of students takes turns leading discussion about specific segment of text through the following strategies: predicting, clarifying, questioning, and summarizing (Palincsar \& Brown, 1984, p. 117).

According to Palincsar \& Brown (1984, p. 127), RT Method offers some advantages for the students, such as providing them a window into the thinking of proficient readers as they problem-solve their way toward meaning; giving the students a condition to approach reading as an active and strategic process; and learning behaviors that will help them become more independent readers, capable of handling increasingly sophisticated material.

Furthermore, it provides explicit teaching through direct instruction that can make obvious what will the students do in reading learning process. It is a sharing of an active comprehension because it involves reciprocal dialogue. It is an important factor in Reciprocal Teaching method which is based on the premise that group participation and dialogue that can aid learning as well as promoting conceptual change (Meyer, 2010, p. 42). This strategy also provides higher order thinking (Meyer, 2010, pp. 
43-47). This strategy encouraging the students to create their own questions based on the text for deeper comprehension. When creating and answering the questions, the students will develop critical thinking ability to engage them in reading and also deepen their understandings that enable all students to experience success with their learning.

\section{Discussion}

\subsection{Reading Comprehension}

Reading is the process of recognizing, interpreting, and perceiving the written or printed material. According Braunger and Lewis (2001, p. 4) reading is a complex and purposeful socio-cultural, cognitive, and linguistic process in which readers simultaneously use their knowledge of spoken and written language, their knowledge of the topic of the text, and their knowledge of their culture to construct meaning with text.

Comprehension is necessary if one wishes to learn from textbooks and manuals, enjoy great literature, or simply follow directions in a cookbook. It constitutes an activity of associating or connecting a reader's ideas or thoughts with what an author states in print. Blair-Larsen and Williams (1999, p. 37) state that comprehension is a multidimensional thinking process; it is the interaction of the reader, the text, and the context. They further point out that comprehension occurs when readers make critical connections between their prior knowledge and new-found knowledge in the text. While reading a text, readers activate their prior knowledge or schemata about a topic. In other words, when a reader or student encounters a reading text, he tries to associate his prior knowledge and what has been written in print. If this happens, it can be said that reading conveys understanding. Otherwise, reading without comprehension cannot be associated as reading since reading is directed to achieve comprehension.

\subsubsection{Models of Reading Process}

To understand the content of a particular text, one must go through a process. During the reading process, a reader might use one, two, or combination of the two models. The models of reading process are bottom-up, top-down, and interactive model.

\section{Bottom-up Model}

The bottom-up model of reading ability is primarily concerned with the recognition of individual letters, phonemes and words. Gough, La Berge and Samuels as quoted by Cox (1999) state that bottom-up reading model views reading as a part to whole process. First, the reader learns to recognize letters, followed by words, and then words in context, until he or she finally begins to understand what is read. This model believes that the reading process begins with individual recognition of letter and phonemic counterparts. This knowledge then leads to the recognition of individual words of the text presented to the reader. Meaning of the whole text is a process of building understanding of individual letters to the word level, then to the sentential level, and finally the text level.

\section{Top-down Model}

The top-down model of reading process places the emphasis on the reader's active participation in the Published by SCHOLINK INC. 
reconstruction of the meaning in the text. Stanovich as quoted by O'Malley and Pierce (1996) states that the model by starting with the reader's hypotheses and predictions about the text and his or her attempts to confirm them by working down to the smallest units of the printed page. Similarly, Cox (1999, p. 270) states that top-down reading views reading as part of language development and a process of hypothesis testing in which the reader's job is to make predictions about the meaning of what is being read.

\section{Interactive Model}

Cox (1999, p. 270) points out that interactive model views the reading process as an interaction between the reader and the text. The model allows for both bottom-up and top-down processing and is reflected in teaching approaches that emphasize direct reading instruction of word identification skills, vocabulary, and word meaning and comprehension. Interactive model is suitable for skilled readers. For them, both bottom-up and top-down models of reading can occur simultaneously. It means that when such readers are confronted with the reading texts, they must activate both their linguistic competences and their schemata related to the text contents.

\subsubsection{Levels of Reading Comprehension}

To know to what extent students have understood the content of the text, some experts have proposed some levels of reading comprehension. Four levels of comprehension as identified by Burns, Roe, and Ross (1996) are discussed. They are reading the lines (literal comprehension), reading between the lines (interpretive or inferential comprehension), reading for evaluation (critical reading), and reading beyond the lines (creative comprehension) each of which can be described in the following section.

\section{Literal Comprehension}

Burns et al. (1996, p. 255) explain that literal reading comprehension involves acquiring information that is directly stated in the text. It is a prerequisite for higher level understanding. To be better in this comprehension one should have a thorough understanding of vocabulary, sentence meaning, and paragraph meaning. They also say that the basis of the literal comprehension is recognizing stated main idea and details. Details in reading mean the specific explicitly-stated parts of a paragraph or passage that contains the basic information. Main idea is the central thought around which a whole paragraph is organized. It is often expressed in a topic sentence. Moreover, it is stated that recognizing and understanding the cause and effect relationship as well as sequence in a written passage is also important to be the basis of literal reading comprehension. Finding out the cause and effect relationship in the reading text is considered as literal skill when the relationship is explicitly stated. Sequence, the order in which events in a paragraph or passage occur, can be identified by time-order words, for example now, before, when, while, yet, after, and so on.

Furthermore, they say that the next basis for literal reading comprehension is direction. The ability to read and follow directions is prerequisite for successful school work. It involves understanding details and sequence; therefore, the exercises under the headings are appropriate to use in teaching students to follow written direction. 


\section{Interpretive/inferential Reading Comprehension}

Based on Burn et al.'s opinion (1996, p. 263), interpretive reading involves making inference or reading between the lines. Moreover, they explain that it is the process of deriving ideas that are implicitly stated. Skills included in this comprehension are 1) inferring the implicit main idea of the passages, 2) inferring cause and effect relationship which are not directly stated, 3) inferring referents of pronouns, 4) inferring referents of adverbs, 5) inferring omitted words, 6) detecting mood, 7) detecting the author's purpose in writing, and 8) drawing conclusions.

\section{Critical Reading Comprehension}

Critical reading is evaluating written material-comparing the ideas discovered in the material with known standards and drawing conclusions about their accuracy, appropriateness, and timeliness. The critical reader must be an active reader, questioning, searching for facts, and suspending judgment until he or she has considered all the material. Critical reading depends on both literal and interpretive comprehension, and grasping implied ideas is especially important.

\section{Creative Reading Comprehension}

Creative reading involves going beyond the material presented by the author. Like critical reading, creative reading requires readers to think as they read, and it also requires them to use their imagination. Such reading results in the production of new ideas. To go beyond the material in the text, readers must make use of their background schemata, combining this prior knowledge with ideas from the text to produce a new response based on, but not completely dictated by, the text. Therefore creative readers must be skilled in the following areas : a) predicting outcomes, b) visualization, c) solving problems, d) improving story presentation, and e) producing new creations (Burn et al., 1996, pp. 293-296).

\subsection{The Nature of Reciprocal Teaching Method}

According to Suparna (2014, p. 15) Reciprocal Teaching is a reading strategy which starts as an oral dialogue among teacher, student, and text. In this case, Reciprocal Teaching is a kind of cooperative learning that needs students involved in group discussion guided by the teacher with an explicit instruction. Moreover, Doolittle et al. (2006, pp. 106-107), specifically, Reciprocal Teaching consists of three main components, (a) the teaching and learning of specific reading comprehension strategies, (b) the dialogue between an instructor and students where the instructor models why, when, and where to use these reading comprehension strategies, and (c) the appropriating of the role of the instructor by the students, that is, students begin to model the reading comprehension strategies for other students.

They stated that the goals of Reciprocal Teaching are for students to learn the reading comprehension strategies, learn how and when to use the strategies, and become self-regulated in the use of these strategies. The four comprehension strategies that traditionally constitute Reciprocal Teaching are predicting, clarifying, questioning and summarizing (Meyer, 2010, p. 41). Oczkus (2010, p. 6) introduced it as "The Fab Four" strategies to make it friendlier with the students. "The Fab Four" strategies introduced elements of fun and adventure, as well as costumes and props to accomplish the goal i.e. the students remember "The Fab Four", so they can get the impact and they can use the Published by SCHOLINK INC. 
strategies independently (Stricklin, 2011, p. 620).

\subsection{Procedures of Reciprocal Teaching Method}

According to Oczkus (2013, p. 35) the steps of Reciprocal Teaching as follows: 1) Predict. Students draw inferences and use evidence from the text throughout the reading process. 2) Question. Students ask and answer questions to understand the text. They draw on multiple sources, including digital items, to answer questions. 3) Clarify. Students know and apply grade level phonics and word analysis skills in decoding words in texts. They also use context to confirm or self-correct, and they reread when necessary. 4) Summarize. Students can identify main ideas and details in paragraphs and in multi paragraph texts. They also compare and contrast the overall structure of a text.

\subsection{Benefits of Reciprocal Teaching Approach}

Reciprocal Teaching, based on the explanation above, has many advantages. It provides explicit teaching through direct instruction that can make obvious what will the students do in reading learning process. It is a sharing of an active comprehension because it involves reciprocal dialogue (one of an important factor in Reciprocal Teaching) which is based on the premise that group participation and dialogue that can aids learning as well as promoting conceptual change (Meyer, 2010, p. 42).

Besides, Reciprocal Teaching had proved to be effective in enhancing the students' comprehension through many researches that have been expanded (Todd \& Tracey, 2006; Bess, 2007; Sarasti, 2007; Yoosabai, 2009; University of Western Illinois, 2010; Freihat \& Al-Makhzoomi, 2012; Salehi \& Vafakhah, 2013; Hou, 2015; Oczkus, 2010). Reciprocal Yeaching not only helps the students to comprehend a text but it can also uses in solving mathematics problems (Quirk, 2010; Meyer, 2014) and musical understanding (Abrahams \& Abrahams, 2010). It means that Reciprocal Teaching has developed as a strategy that can help the students in wide coverage of understanding. In short, this strategy can be considered as a good strategy to enhance students' comprehension because it can be applied in any school subjects.

\subsection{Reciprocal Teaching Strategy in Teaching Reading}

A model of Reciprocal Teaching strategy for the teaching of reading can be developed into pre, while, and post reading activities (See Table 1 below).

Table 1. Model of Teaching Reading Using Reciprocal Teaching Strategy

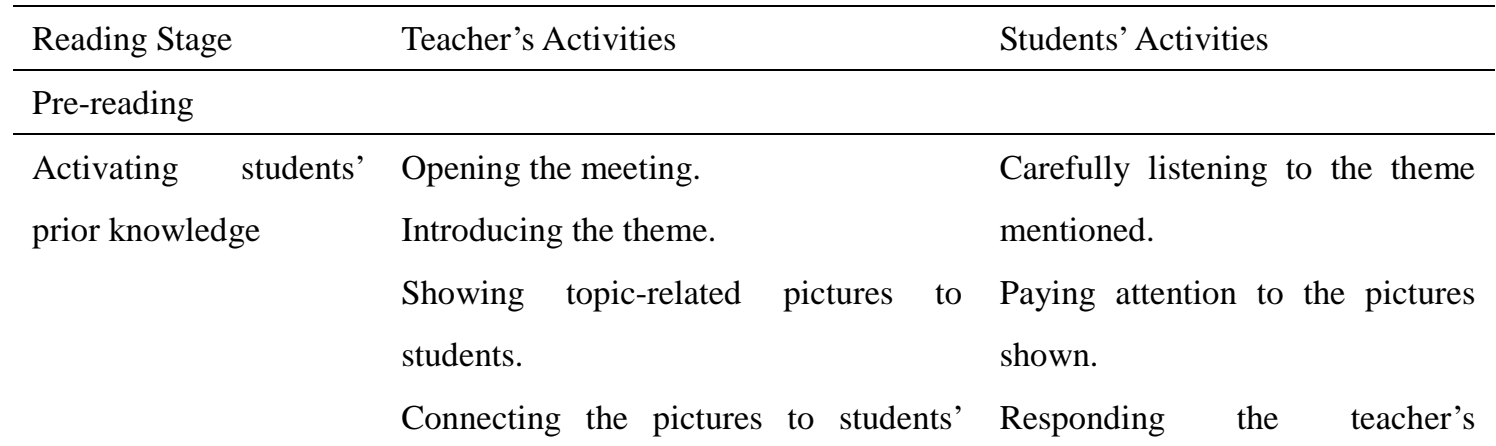




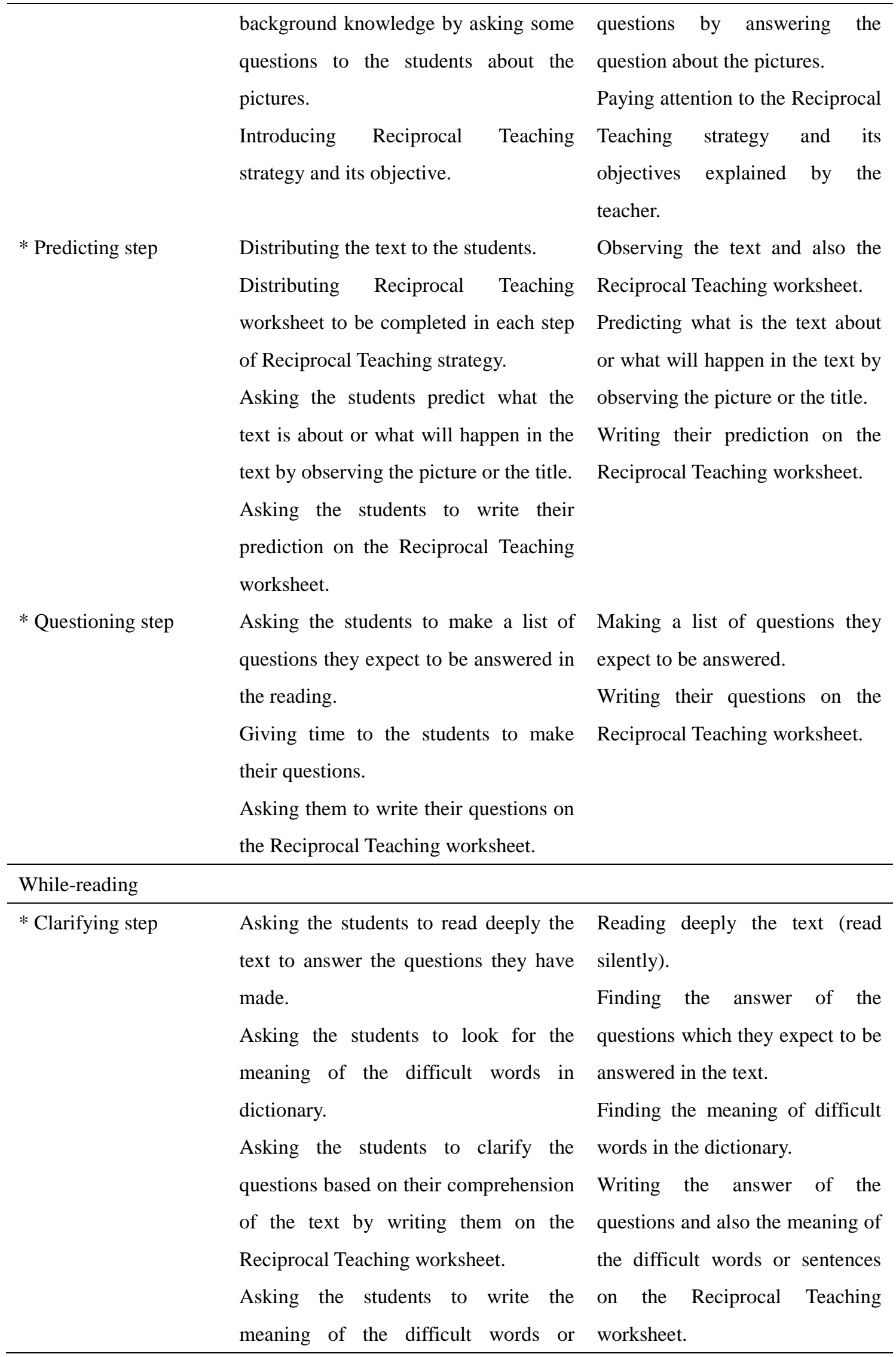




\begin{tabular}{|c|c|c|}
\hline & $\begin{array}{l}\text { sentences and write them on the } \\
\text { Reciprocal Teaching worksheet. }\end{array}$ & \\
\hline \multicolumn{3}{|l|}{ Post-reading } \\
\hline * Summarizing step & $\begin{array}{l}\text { Asking the students to analyze their } \\
\text { answers. } \\
\text { Asking the students to summarize the } \\
\text { main point or the conclusion of the text } \\
\text { with their own words. } \\
\text { Asking the students to write their } \\
\text { summary on the Reciprocal Teaching } \\
\text { worksheet. } \\
\text { Asking the students to deliver their } \\
\text { summarize result in front of class. } \\
\text { Asking the students to collect their } \\
\text { works. } \\
\text { Closing the meeting. }\end{array}$ & $\begin{array}{l}\text { Analyzing their answer. } \\
\text { Summarizing the text. } \\
\text { Writing their summaries on the } \\
\text { Reciprocal Teaching worksheet. } \\
\text { Delivering their summaries in } \\
\text { front of class. } \\
\text { Collecting their works to the } \\
\text { teacher. }\end{array}$ \\
\hline
\end{tabular}

\section{Conclusion and Suggestion}

Reciprocal Teaching Method is one of reading comprehension methods that encompasses four activities as follows: 1) Predict. Students draw inferences and use evidence from the text throughout the reading process. 2) Question. Students ask and answer questions to understand the text. 3) Clarify. Students know and apply grade level phonics and word analysis skills in decoding words in texts. They also use context to confirm or self-correct, and they reread when necessary. 4) Summarize. Students can identify main ideas and details in paragraphs and in multi paragraph texts. This method appears to be the most appropriate for students because it provides high order thinking instructional strategy that can make the students fully engaged in reading learning process.

\section{References}

Abrahams, F., \& Abrahams, D. (2010). The Impact of Reciprocal Teaching on the Development of Musical Understanding in High School Student Members of Performing Ensembles: An Action Research. In Visions of Research in Music \& Education (Vol. 15). Princeton, NJ: Westminster Choir College of Rider University.

Alderson, J. C. (1984). Reading in A Foreign Language: Reading Problem? In J. C. Alderson, \& A. H. Urquhant (Eds.), Reading in a Foreign Language (pp.1-27). New York: Longman.

Bess, B. R. (2007). The Effects of Reciprocal Teaching Strategies on Students' Comprehension of a Seventh Grade Life Science Text (A Thesis Submitted in Partial Fulfillment of The Requirements 
for The Degree of Master of Education in the Department of Teaching and Learning Principles). Orlando, FL: University of Central Florida.

Blair-Larsen, S. M., \& Williams, K. A. (1999). The Balanced Reading Program. In Helping All Students Achieve Success. Delaware: International Reading Association, Inc.

Braunger, J., \& Lewis, J. P. (2001). Building a Knowledge Base in Reading (2nd ed). Delaware: International Reading Association.

Burns, C. P., Roe, D. B., \& Ross, P. E. (1996). Teaching Reading in Today's Elementary School. Houghton, USA: Mifflin Company.

Chawwang, N. (2008). An Investigation of English Reading Problems of Thai 12th-Grade Students in Nakhonratchasima Educational Regions 1, 2, 3 and 7 (A Thesis Presented in Partial Fulfilment of the Requirements for the Master of Arts Degree in English). Bangkok, Thailand: Srinakharinwirot University.

Cox, C. (1999). Teaching Language Arts. In A Student-and Response-Centered Classroom (3rd ed). Needham Heights, MA: Allyn and Bacon.

Djiwandono \& Soenardi, M. (1996). Tes Bahasa dalam Pengajaran. In FPBS-IKIP Malang. Penerbit: ITB Bandung.

Doolittle, P. E., Hicks, D., Triplett, C. F., Nichols, W. D., \& Young, C. A. (2006). Reciprocal Teaching for Reading Comprehension in Higher Education: A Strategy for Fostering the Deeper Understanding of Texts. International Journal of Teaching and Learning in Higher Education, 17(2), 106-118.

Freihat, S., \& Al-Makhzoomi, K. (2012). The Effect of the Reciprocal Teaching Procedure (RTP) on Enhancing EFL Students' Reading Comprehension Behavior in a University Setting. International Journal of Humanities and Social Science, 2(5), 279-291.

Gillet, J. W., \& Temple, C. (1994). Understanding Reading Problems: Assessment and Instruction (4th ed). New York: Jean Wallace Gillet and Charles Temple.

Hou, Y. J. (2015). Reciprocal Teaching, Metacognitive Awareness, and Academic Performance in Taiwanese Junior College Students. International Journal of Teaching and Education, III (4), 15-32. https://doi.org/10.20472/TE.2015.3.4.003

Leipzig \& Henry, D. (2001). What is Reading? WETA. Retrieved April 14, 2007, from http://www.readingrockets.org/article/352.

Meyer, K. (2010). “Diving into Reading”: Revisiting Reciprocal Teaching in the Middle Years. Literacy Learning: The Middle Years, 18(1), 41-52.

Meyer, K. (2014). Making Meaning in Mathematics Problem-Solving Using the Reciprocal Teaching Approach. Literacy Learning: The Middle Years, 22(2), 7-14.

Nunan, D. (1991). Language Teaching Methodology: A Textbook for Teacher. New York: Prentice Hall, Inc.

O’Malley, J. M., \& Pierce, L. V. (1996). Authentic Assessment for English Language Learners. In Published by SCHOLINK INC. 
Practical Approaches for Teachers. Addison-Wesley Publishing Company.

Oczkus, L. (2010). Reciprocal Teaching at Work: Powerful Strategies and Lessons for Improving Reading Comprehension (2nd ed). Newark, DE: International Reading Association.

Palincsar, A. S., \& Brown, A. L. (1984). Reciprocal Teaching of Comprehension Fostering and Comprehension Monitoring Activities. Cognitive and Instruction, 1(2), 117-175. https://doi.org/10.1207/s1532690xci0102_1

Quirk, P. J. (2010). Using Reciprocal Teaching and Learning Methods to Enhance Comprehension in Mathematics Word Problems. In A Thesis Presented in Partial Fulfillment of the Requirements for the Degree of Master of Education. Palmerston North, New Zealand: Massey University.

Rahman, Md. H. (2007). An Evaluation of the Teaching of Reading Skills of English in Bangladesh. In A Thesis Submitted in Partial Fulfilment of the Requirements for the Degree of MA in English. Rajshahi, Bangladesh: University of Rajshahi.

Salehi, M., \& Vafakhah, S. (2013). A Comparative Study of Reciprocal Teaching Only (RTO) and Explicit Teaching of Strategies before Reciprocal Teaching (ET-RT) on Reading Comprehension of EFL Learners. Australian Journal of Basic and Applied Sciences, 7(2), 148-155.

Sarasti, I. A. (2007). The Effects of Reciprocal Teaching Comprehension Monitoring Strategy on 3rd Grade Students' Reading Comprehension. In Dissertation Prepared for the Degree of Doctor of Education. Denton, TX: University of North Texas.

Stricklin, K. (2011). Hands-On Reciprocal Teaching: A Comprehension Technique. The Reading Teacher, 64(8), 620-625. https://doi.org/10.1598/RT.64.8.8

Suparna, K. (2014). Improving Reading Comprehension through Reciprocal Technique to the Tenth Grade Student of SMK PGRI 4 Denpasar in Academic Year 2013/2014 (A Thesis as Partial Fulfillment of the Requirements for the Sarjana Pendidikan Degree in English Education Study Program Faculty of Teacher Training and Education). Denpasar, Bali: Mahasaraswati Denpasar University.

Todd, R. B., \& Tracey, D. H. (2006). Reciprocal Teaching and Comprehension: A Single Subject Research Study (Partial Fulfillment of the Requirements for the Master of Arts Degree in Reading Specialization). Union, NJ: Kean University.

University of Western Illinois. (2010). Reciprocal Teaching and Reading Comprehension. In Elementary Education Graduate Candidate Work. Macomb, IL: Western Illinois University.

Yaseen, A. (2013). The reading difficulties in English and how to deal with them as perceived by teachers and students in Nablus district (A Thesis Submitted in Partial Fulfilment of the Requirements for the Degree of Master of Teaching Method, Faculty of Graduate Studies). Nablus, Palestine: An-Najah National University.

Yoosabai, Y. (2009). The Effects of Reciprocal Teaching on English Reading Comprehension in a Thai High-School Classroom (A Dissertation Presented in Partial Fulfillment of the Requirements for the Doctor of Philosophy Degree in English). Bangkok, Thailand: Srinakharinwirot University. 